\title{
鉄筋コンクリート造開断面立体耐震壁の構造性能に関する研究 STRUCTURAL CAPACITIES OF OPEN-SECTION R/C CORE WALLS
}

\author{
丸田 誠*, 鈴木 紀 雄**, 別所 佐登志*** \\ Makoto MARUTA, Norio SUZUKI and Satoshi BESSHO
}

\begin{abstract}
Recently, several high-rise RC buildings with a core wall have been designed and constructed. Due to demands of architectural planning, these core walls often become open section walls. Bending and shear loading tests and analyses were conducted for evaluating the structural capacities of the open section core walls. Major conclusions obtained from the tests and the analyses are as follows;

1. In designing and analyzing the open section core walls, their loading directions must be taken into consideration since their structural behavior varies largely with the loading directions.

2. The test results can be well simulated by a fiber model bending analysis based on the linear strain assumption.

3. The lateral displacement which is calculated by a fiber model bending analysis, adding the shear displacement as well as the displacement caused by slip away from the foundation, can simulate the test results.

4. The ultimate bending strength for the core wall calculated by a fiber model analysis assuming the limitation of $0.3 \%$ concrete strain or $1.0 \%$ longitudinal rebar strain, can estimate conservatively the test results.

5. The required design ductility of the core wall can be obtained by confining the compression area concrete of a wall-column by lateral reinforcements. The required design curvature corresponding to the allowable lateral displacement, is assured by the proposed calculation method using a fiber model analysis. The results from this method can simulate conservatively the test results.
\end{abstract}

Keywords: High-rise RC structure,Corewall system,3D-shear wall, Open section, High strength materials, Structural behavior, Design method 高層 R C 建物, コア壁架構, 立体耐震壁, 開断面, 高強度材料, 構造性能, 設計法

1. はじめに

近年，我が国の超高層建物においても，高強度材料を使用した鉄 筋コンクリート造（以下 R C と称す）立体耐震壁（以下コア壁と称 す）を主要な耐震要素とするコア壁架構が活用されるようになって きた 1)，2)。この場合，コア壁は複数のL 形断面等の壁を境界梁で 繋ぎ全体的に閉断面立体耐震壁架構とし，曲げ性能を高めるのが一 般的であり，その構造性能に関する検討も数多く実施されるように なった ${ }^{3) 〜 6) 。 ~}$

近年, 図1に示すようにコア壁と制震装置を用い, かつ建物内部 に梁及び柱のない高層 R C 架構法が提案された7)。コア壁はエレべ 一ターや階段室を設ける都合から, 設計上開断面とする方が自由度 が高い。さらに，コア壁を開断面の独立耐震壁とすることにより， 曲げ変形が大きくなり最上階の大梁を介して制震装置を有効に㗢か せる効果も期待される。よって, H形や E 形断面をした開断面コア 壁が,この架構に採用される場合も多い。

コア壁架構の場合, 地震時にコア壁脚部に大きな曲げモーメント が作用し，その曲げ勒性能が耐震性を左右する。しかし，開断面コ ア壁に関しては既往の研究例は無く、このような架構を実現するた めには曲げモーメント及びせん断力に対するコア壁の構造性能を把 握し, 耐震設計法の確立が重要となる。そこで本研究では, コア壁
の復元力特性とひび割れや鉄筋降伏などの各耐力点や終局利力, 変 形能力等を構造実験により把握した。次に終局耐力実験值と平面保 持を仮定した断面曲げ解析法（ファイバーモデル）や既往の提案式 で計算した耐力を比較した。ま た，断面曲げ解析を主体とし， せん断変形及び基礎からの縦筋 の抜け出しによる変形の影響を 取り入れた復元力特性の評価法 を提案し解析結果を実験結果と 比較した。さらに, 設計で必要
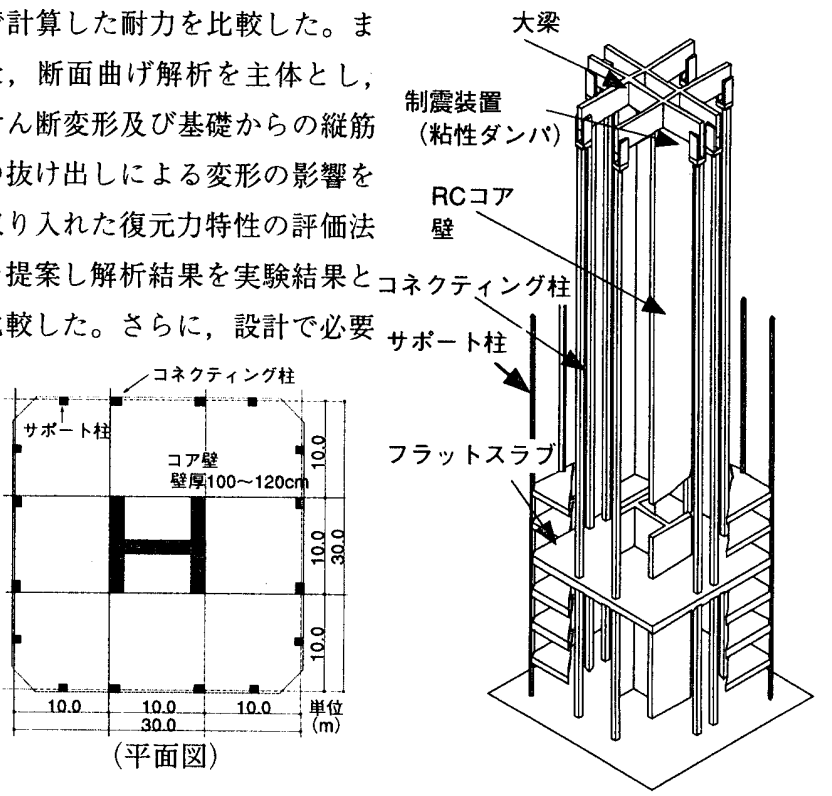

図 1 制震装置を有する超高層 R C 架構例 7 )

\footnotetext{
* 鹿島技術研究所 主任研究員・工修

** 鹿島技術研究所 主管研究員 ·工博

*** 鹿島技術研究所 専門部長

Senior Research Engineer, Kajima Technical Research Institute, Kajima Corp., M. Eng.

Chief Research Engineer, Kajima Technical Research Institute, Kajima Corp., Dr. Eng.

Senior Manager, Kajima Technical Research Institute, Kajima Corp.
} 
となる終局酎力の適切な定義と, 必要な変形能力を確保する

表 1 試験体一覧

ための横補強筋（拘束筋）の設計法を提案し，その妥当性を 検証した。

\section{2 .構造実験}

\section{1 実験計画}

高強度コア壁脚部の構造性能把握のために実物の1/6.7縮尺 の同一断面・形状をもつH形断面壁4体, E形断面壁1体の計5 体の試験体について水平加力実験 ${ }^{8)}$ を行った。試験体の一覧 を表 1 に，形状・配筋を図2に示す。試験体には壁厚の 2 倍の 長辺を有する長方形の内蔵柱型を設け，その部分を横補強筋 で拘束した。H形の3 体は, 強軸(No.1：ウエブ壁となす角度

\begin{tabular}{|c|c|c|c|c|}
\hline 試験体名 & 試験体形状 & 加力方向 & $\mathrm{M} / \mathrm{OLw}$ & 備 考（共通） \\
\hline No.1 & \multirow{3}{*}{$\square$} & $\underset{(\text { 强㖕方向) }}{\longrightarrow}$ & \multirow{2}{*}{7.0} & \multirow{3}{*}{ 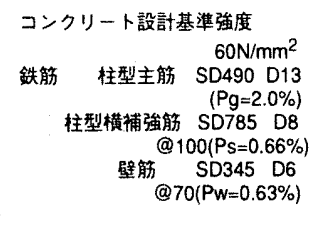 } \\
\hline No.2 & & $1_{\text {(弱特方向) }}$ & & \\
\hline No.3 & & & 4.95 & \\
\hline No.4 & & $\underset{\text { (强鐵方向) }}{\longrightarrow}$ & 7.0 & \multirow{2}{*}{$\begin{array}{l}\text { 軸応力度 } \sigma_{0}=6 \mathrm{~N} / \mathrm{mm}^{2}(0.1 \mathrm{Fc}) \\
\text { No.1,No.2,No.3,No.5 } \\
\text { 軸力 } \mathrm{N}=3435 \mathrm{kN}\end{array}$} \\
\hline & & $\leftrightarrow$ & & \\
\hline No. 5 & & 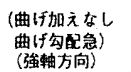 & 2.23 & No.4 軸力 $\mathrm{N}=3111 \mathrm{kN}$ \\
\hline
\end{tabular}

綎, 横筋 D6（SD345） CL

$\mathrm{Pw}_{\mathrm{w}}=0.63 \%$ (@70) 23-D 13 (SD490)

水平力P1

保(100t汭ャッキ4本の水平方向の合計)
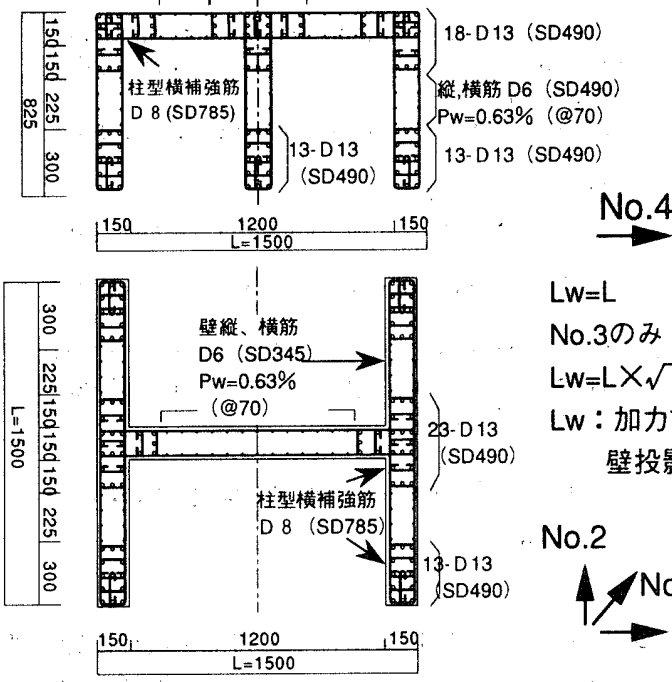

$\mathrm{L} W=\mathrm{L}$

No.3のみ

$L W=L X \sqrt{2}$

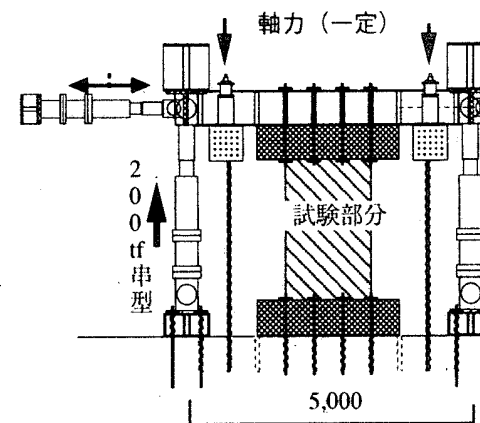

Lw：加力方向への

壁投影長さ

No.2

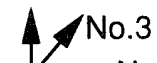

$\rightarrow$ No.1,No.5

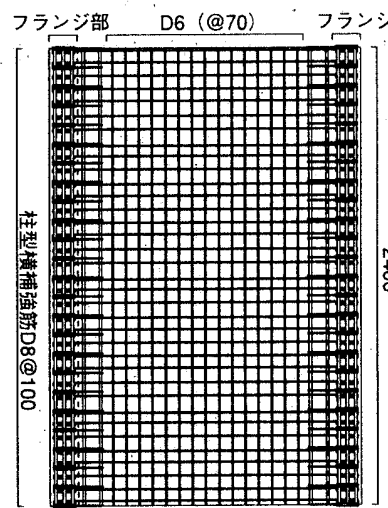

図 2 試験体形状・配筋

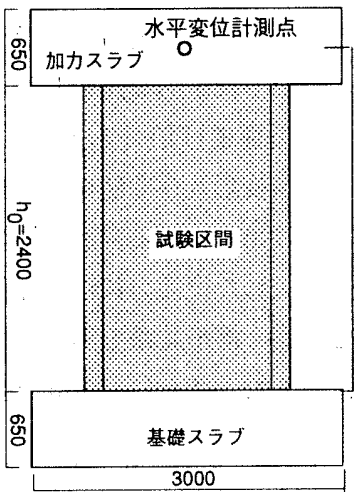

(頂部モーメント)

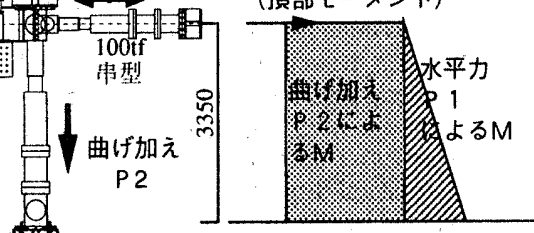

(脚部モーメント)

$P 1:$ 水平力の合計

P2: $200 \mathrm{t}$ ジャッキ1本の荷重

* : No.5では曲げ加えは行わない

図3 加力方法

表 2 使用材料の力学的性質

(コンクリート）

\begin{tabular}{|c|c|c|c|c|c|}
\hline \multirow[b]{2}{*}{ 試験体名 } & \multicolumn{4}{|c|}{ 陚 联 時 封 絾 } & \multirow[b]{2}{*}{ 備考 } \\
\hline & $\begin{array}{c}\text { 圧縮強度 } \\
\left(\mathrm{N} / \mathrm{mm}^{2}\right)\end{array}$ & \begin{tabular}{|c|} 
弾性係数 \\
$\left(\times 10^{4} \mathrm{~N} / \mathrm{mm}^{2}\right)$
\end{tabular} & ポアンン比 & 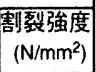 & \\
\hline$\overline{\mathrm{No.1}(\mathrm{HO})}$ & 62.5 & 3.25 & 0.18 & 3.61 & 53日強度 \\
\hline No.2(H 90) & 65.7 & 3.08 & 0.19 & 4.16 & 71日強度 \\
\hline $\mathrm{No} .3(\mathrm{H} 45)$ & 61.0 & 3.27 & 0.18 & 4.00 & 88日強度 \\
\hline No.4(E0) & 67.0 & 3.37 & 0.17 & 3.36 & 65日強度 \\
\hline $\mathrm{No.5}(\mathrm{HO})$ & 56.3 & 3.13 & 0.18 & 3.17 & 47日強度 \\
\hline
\end{tabular}

(鉄筋)

\begin{tabular}{|c|c|c|c|c|c|c|c|c|}
\hline 径 & 材質 & $\begin{array}{c}\text { 㦀伏点 } \\
\sigma y \\
\text { oy } \\
\text { N } / \mathrm{mmm}\end{array}$ & $\begin{array}{l}5 \text { 張强さ } \\
\text { of } \\
(\mathrm{N} / \mathrm{mm})\end{array}$ & $\begin{array}{l}\text { 降伏比 } \\
\sigma \quad y / \sigma\end{array}$ & 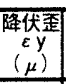 & $\begin{array}{l}\text { 伸U } \\
(\%)\end{array}$ & 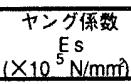 & 㣁考 \\
\hline D6 & SD345 & 379 & 491 & 0.77 & 2110 & 32.8 & 1.88 & 壁街栱筋 \\
\hline D8 & SD785 & 873 & 1066 & 0.82 & 6300 & 9.2 & 2.04 & 柱型聩㭪強能 \\
\hline D13 & SD490 & 576 & 721 & 0.80 & 3060 & 17.4 & 1.90 & 柱型主筋 \\
\hline
\end{tabular}

注) 降伏歪、伛力は $0.2 \%$ オセット法による

表 3 実験結果一覧

\begin{tabular}{|c|c|c|c|c|c|c|c|c|c|c|c|c|c|c|c|c|c|}
\hline \multirow{3}{*}{ 試験体名 } & \multirow{3}{*}{ 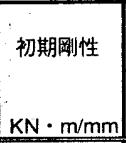 } & \multirow{2}{*}{\multicolumn{2}{|c|}{$\begin{array}{l}\text { 初期ひび割れ } \\
\text { (曲げ) }\end{array}$}} & \multirow{2}{*}{\multicolumn{2}{|c|}{ 柱主筋王樎降伏 }} & \multirow{2}{*}{\multicolumn{2}{|c|}{ 柱主筋引引張降伏 }} & \multirow{2}{*}{\multicolumn{2}{|c|}{$\begin{array}{c}\text { 柱型横補強筋 } \\
\text { 降伏 } \\
\end{array}$}} & \multirow{2}{*}{\multicolumn{2}{|c|}{ 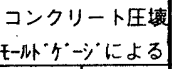 }} & \multirow{2}{*}{\multicolumn{2}{|c|}{ 壁横施降伏 }} & \multicolumn{4}{|c|}{ 最大耐力 } \\
\hline & & & & & & & & & & & & & & & & 負加 & \\
\hline & & \begin{tabular}{|c|} 
荷重 \\
$\mathrm{KN} \cdot \mathrm{m}$ \\
\end{tabular} & $\begin{array}{l}\text { 変位 } \\
\mathrm{mm}\end{array}$ & \begin{tabular}{|c|} 
荷重 \\
$\mathrm{KN} \cdot \mathrm{m}$
\end{tabular} & $\begin{array}{l}\text { 変位 } \\
\mathrm{mm}\end{array}$ & \begin{tabular}{|c|} 
荷重 \\
$\mathrm{KN} \cdot \mathrm{m}$ \\
\end{tabular} & $\begin{array}{l}\text { 変位 } \\
\mathrm{mm}\end{array}$ & $\begin{array}{r}\text { 荷重 } \\
\mathrm{KN} \cdot \mathrm{m}\end{array}$ & $\begin{array}{l}\text { 変位 } \\
\mathrm{mm}\end{array}$ & $\begin{array}{c}\begin{array}{c}\text { 荷重 } \\
\mathrm{KN} \cdot \mathrm{m}\end{array} \\
\end{array}$ & $\begin{array}{l}\text { 変位 } \\
\mathrm{mm}\end{array}$ & $\begin{array}{r}\text { 荷重 } \\
\mathrm{KN} \cdot \mathrm{m} \\
\end{array}$ & $\begin{array}{l}\text { 変位 } \\
\mathrm{mm}\end{array}$ & $\begin{array}{c}\text { 荷重 } \\
\mathrm{KN} \cdot \mathrm{m} \\
\end{array}$ & $\begin{array}{l}\text { 变位 } \\
\mathrm{mm}\end{array}$ & $\begin{array}{r}\text { 荷重 } \\
\mathrm{KN} \cdot \mathrm{m} \\
\end{array}$ & $\begin{array}{l}\text { 変位 } \\
\mathrm{mm} \\
\end{array}$ \\
\hline $\begin{array}{l}\text { No.1 } \\
(\text { (H型・方向) }\end{array}$ & 1320 & 3240 & 2.46 & $-\infty$ & --- & 8050 & 23.0 & -- & -- & 8680 & 106.0 & 7700 & 24.0 & 8730 & 106.0 & -8420 & -54. \\
\hline $\begin{array}{l}\text { No.2 } \\
\left(\left.\mathrm{H}^{\prime}\right|^{\dagger} \text { 方向 }\right)\end{array}$ & 677 & 1660 & 2.45 & 5270 & 18.0 & 4760 & 15.0 & 6420 & 53.0 & 3540 & 14.0 & $-\cdots$ & -- & 6630 & 48.0 & .5910 & -26 \\
\hline $\begin{array}{l}\text { No.3 } \\
\text { (H型〉方) }\end{array}$ & 867 & 1690 & 1.95 & 6240 & 18.0 & 4060 & 10.0 & --- & -- & 6230 & 18.2 & 7390 & 33.0 & 7390 & 33.1 & -6950 & -27 \\
\hline $\begin{array}{l}\text { No.4 } \\
\text { (E型! 方向) }\end{array}$ & 783 & 1480 & 1.89 & -7080 & 44.0 & 4700 & 15.0 & --- & $-\cdots-$ & $\cdots-$ & --- & --- & $-\infty$ & 7320 & 54.0 & .7160 & -54 \\
\hline $\begin{array}{l}\text { No.5 } \\
\text { (H型办方向) } \\
\text { せん断破壞型 }\end{array}$ & $\begin{array}{c}192 \\
(\mathrm{KN} / \mathrm{mm})\end{array}$ & $\begin{array}{c}(\text { 女 } \\
658 \\
(\mathrm{KN})\end{array}$ & $\begin{array}{l}\left.-4 \frac{45}{6}\right) \\
8.95\end{array}$ & 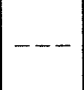 & - & --- & & & & & & $\begin{array}{c}1120 \\
\text { (KN) }\end{array}$ & 18.0 & $\begin{array}{l}1700 \\
(\mathrm{KN})\end{array}$ & 38.0 & & \\
\hline
\end{tabular}

注）表中の変位は図2加カスラブ中央位贯の值

a)：小振幅で綵り返し後，正加力で押し切りのため貣加力末記入 

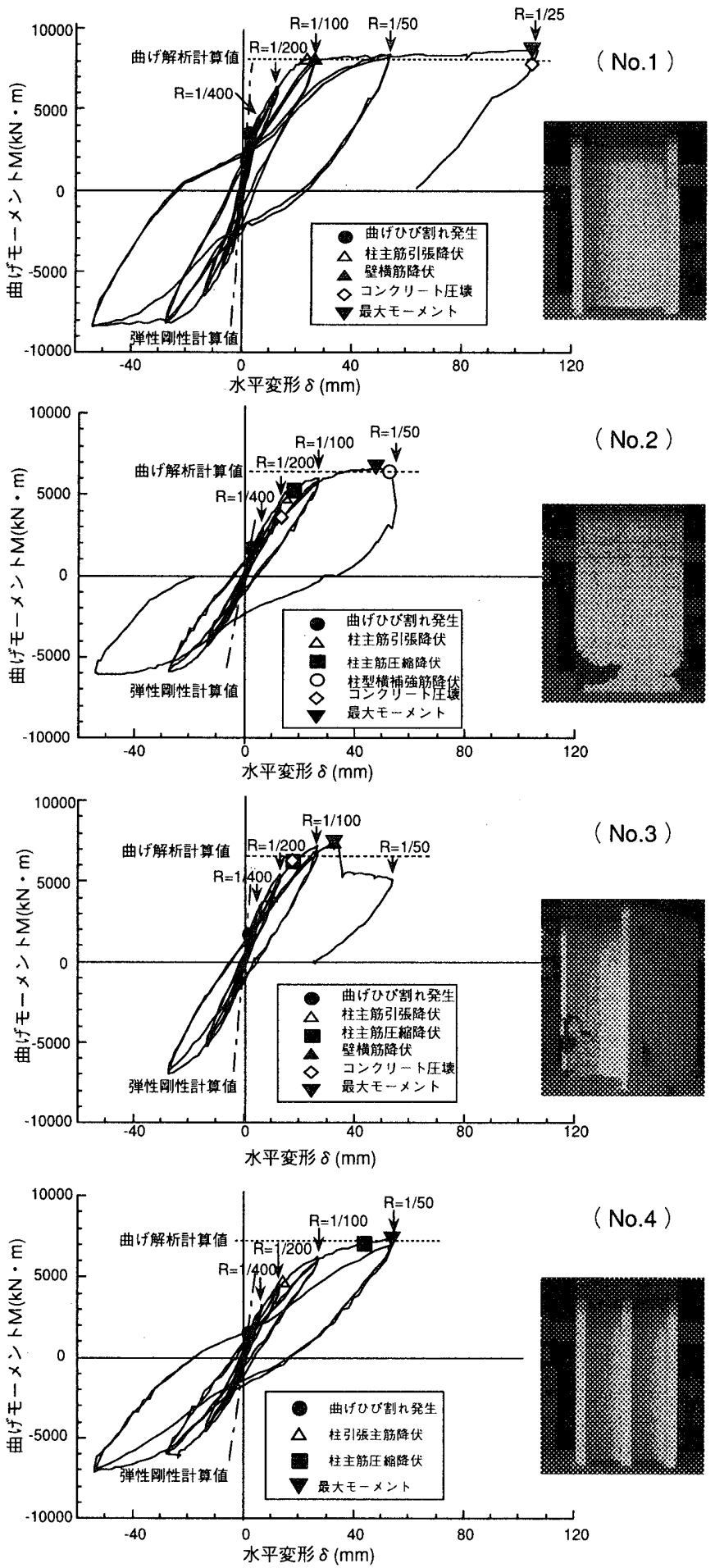

図 4 脚部モーメントー水平変形関係

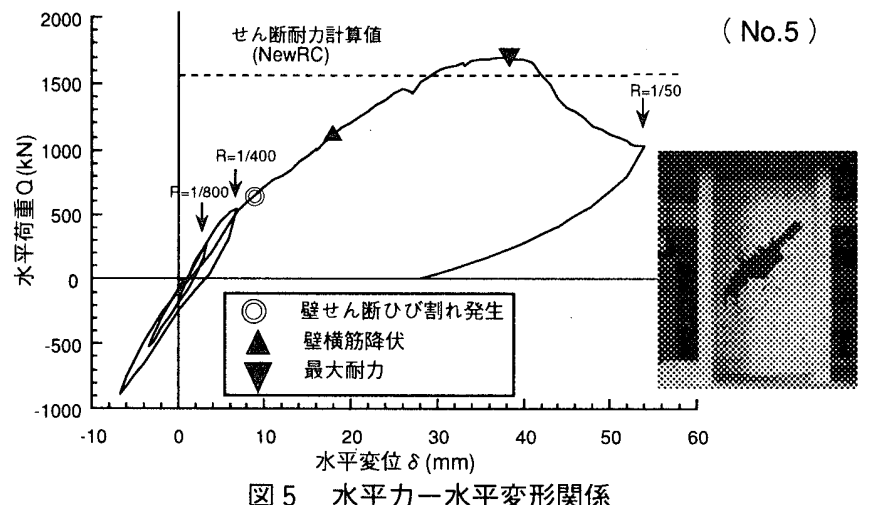

図 5 水平カ一水平変形関係

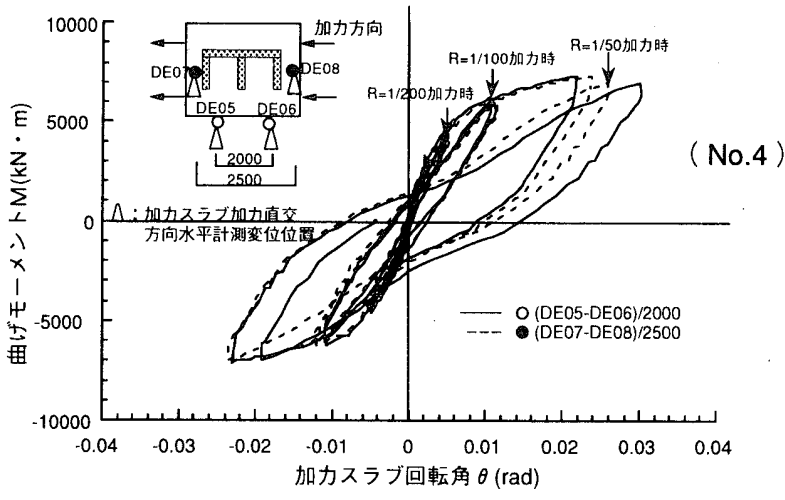

図 6 脚部モーメントー上部スラブ回転角関係

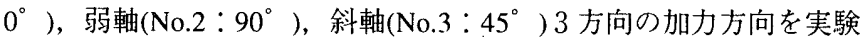
因子とした。E形は強軸方向(No.4: $\left.0^{\circ}\right)$ に加力した。No.5試験体は No.1と同方向の加力であるが，せん断スパン比 $\mathrm{M} / \mathrm{QLw}(\mathrm{M}, \mathrm{Q}$ ：脚 部モーメント, せん断力 $\mathrm{Lw}$ : 加力方向の壁投影長さ) を小さくし てせん断破壊先行形とした。表 2 に材料試験結果を示す。コンクリ 一トは最大骨材径 $10 \mathrm{~mm}$ とし封縅養生供試体で実験時 $\sigma_{\mathrm{B}}=60 \mathrm{~N} / \mathrm{mm}^{2}$ を目標とした。

加力は, 一定軸力下 $\left(0.1 \mathrm{Fc}\right.$ 相当 $\left.6 \mathrm{~N} / \mathrm{mm}^{2}\right)$ で加力スラブ中央の部材 角 $\mathrm{R}(\delta / \mathrm{h})$ で制御し $1 / 800,1 / 400,1 / 200,1 / 100,1 / 50,1 / 25$ を目 標に水平繰り返し加力した。水平加力は, No.1〜No.4までは, 30階 程度の図 1 の架構の 1 次モードに相当する曲げ勾配（強・弱軸 $\mathrm{M} / \mathrm{QLw}=7$ ）を模擬するために，図3に示すように曲げ加えを行った。 No.5は曲げ加えを行わず(M/QLw=2.23), 女ん断破壊先行形とした。

\section{2 実験結果}

実験結果の一覧を表3に示す。No.1〜No.4試験体の脚部モーメン ト一水平変形（加力スラブ中央位置）関係を図4に示す。No.5試験 体の水平力一水平変形関係を図5に示す。最終破壊状況もあわせて 示す。

\section{H形強軸試験体 (No.1: $0^{\circ}$ )}

$\mathrm{R}=1 / 800$ でフランジ壁に曲げひび割れが発生して剛性は低下する が，除荷時には原点に戻る $\mathrm{S}$ 字型の性状を示す。この傾向は $R=1 / 2000$ 繰り返しまで続く。その後, $R=1 / 100$ のピーク近傍でフラ ンジ壁引張側主筋が降伏し，その後の繰り返しでは大きな紡鍾形の ループを描く。 $\mathrm{R}=1 / 50$ の大変形の繰り返しでも耐力低下は生じず, $\mathrm{R}=1 / 25$ までモーメントは若干上がり続けた。 $\mathrm{R}=1 / 25$ 時に圧縮側フラ ンジ脚部のかぶりコンクリートが剥落した。なお，柱型横補強笳の ひずみは $1200 \mu$ 程度の值で降伏は見られなかった。

\section{H形弱軸試験体 (No.2：90 )}

$\mathrm{R}=1 / 200$ までの繰り返しでは, No.1ほど強い $\mathrm{S}$ 字型とはならなか つた。 $\mathrm{R}=1 / 100$ のサクルで柱型主筋の压縮, 引張降伏が生じ紡銛 形のループを描くようになる。 $\mathrm{R}=1 / 100$ ピーク近傍で圧縮側フラン ジ下部のかぶりコンクリートの圧壊が見られた。 $R=1 / 50$ 時にフラン ジ壁脚部近傍の拘束した柱型から少しウエブ寄りの壁部分からコン クリートが圧壊し, 次に柱型横補強筋が降伏し, 軸力が低下した。 その後軸力を再載荷し, 逆（負）方向に加力したところ R=-1/50まで 良好なループを描いた。

\section{H形斜軸試験体 (No.3：4 $5^{\circ}$ )}

$\mathrm{R}=1 / 100$ 程度までは弱軸N 0.2 と同様な性状を示す。 $\mathrm{R}=1 / 100$ ピーク に向かう途中で圧縮側フランジ下部のかぶりコンクリートの圧壊が 
見られた。約 $\mathrm{R}=1 / 80$ 時に最大モーメント $7390 \mathrm{kN} \cdot \mathrm{m}$ となり圧縮側壁 部分から压壊が始まり柱型内も圧壊し柱型主筋の座屈も確認され た。破壊性状としてはNo.2とほほ同様であった。しかし軸力は低下 せず，曲げモーメントも最大の 7 割程度維持していたため, $\mathrm{R}=1 / 50$ まで載荷を行った。平面的に端部フランジのみならず，中央位置近 傍のフランジのコンクリートの圧壊や，多くの壁縦筋の圧縮・引張 降伏が確認された。No.2,No.3では柱型横補強筋の近傍の非拘束部分 からコンクリートが圧壊していることより，拘束部分を拡大すると 更なる耐力・勒性向上が実現できると推測される。

H形断面壁では, 加力方向別によってその勒性能の差が顕著であ り，(1)強軸 $\rightarrow$ (2)弱軸 $\rightarrow$ (3)斜軸の順に勒性が低下する。これは曲げ勒 性能を決めるのが圧縮側のコンクリート部分であり，その圧縮域の 面積が小さくなるとコンクリートの圧縮応力度が高くなり, 上記の 順に勒性が低下したと考えられる。

\section{E形強軸試験体 (No.4:0 $\left.0^{\circ}\right)$}

この試験体では水平加力中心である断面重心とねじり中心がず れ，試験体がねじられるが，このねじりを止めるような制御はして いない。その結果, 図6に示すように頂部の加カスラブの回転角は, 水平変形が $\mathrm{R}=1 / 100$ 時に $\theta=1 / 100$ 程度となり，ねじりの影響が大き いことが分かる。

ウエブ壁側（図2 No.4で上側）と反対のフランジ壁端部側の水平 変位計測值は $1: 5 \sim 1 ： 10$ と大きく異なる結果となった。図4の水平 変位は, これらの平均值である。最大酎力は $\mathrm{R}=1 / 50$ ピーク時に生じ $7320 \mathrm{kN} \cdot \mathrm{m}(\delta=54 \mathrm{~mm})$ となった。試験体は，ねじれながらも曲げ

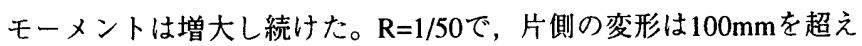
たため実験を終了した。4 隅のエッジ部分のかぶりコンクリートは 圧壊したが，フランジ・ウエブとも横筋の降伏等は確認されず，せ ん断の影響が大きくなかったことが分かった。

\section{H形せん断試験体 $\left(\mathrm{No} .5: 0^{\circ}\right)$}

本試験体はせん断耐力・変形を確認するための試験体でなので $\delta$ $=1 / 800,1 / 400$ の小変形で繰り返した後，片側に押し切った。最大酎 力は $\mathrm{R}=1 / 73$ 時に $\mathrm{Q}=1700 \mathrm{kN}$ （ウエブ壁のみで計算すると, せん断応 力度 $\tau=8.43 \mathrm{~N} / \mathrm{mm}^{2}$ ) となった。その後も軸力保持下で, $\mathrm{R}=1 / 50$ ま で載荷した。 $\mathrm{R}=1 / 50$ 時の水平力は最大耐力の $58 \%$ であった。

\section{3 .実験結果の検討}

\section{1 最大耐力の評価}

既往の最大耐力評価式と実験結果の比較を表4に示す。No.1 No.4では，平面保持を仮定した断面解析（以下ファイバーモデルと 称す) から求めた曲げ最大耐力も含めた。図4中にもその值を示す。 ファイバーモデルで用いたコンクリートの応力ーひずみ関係モ デルを図7に示す。壁内柱型部分の横補強筋による拘束領域は, 孫・崎野9) のモデルとした。それ以外の非拘束領域のコンクリ ートは, Fafitis-Shah ${ }^{10)}$ の式とした。鉄筋の応力ーひずみ関係 はバイリニア型の完全弾塑性とし，降伏強度は実強度を用いた。 このファイバーモデルでの解析耐力値（表4 b)）は, 1.03 1.11 (実験値／計算値）と実験結果と良好に一致した。既往の簡易曲 げ耐力評価式（表4 a)）でも実験結果を安全側に評価できた。た だし評価する長さや幅，鉄筋断面積等は表 4 下a)に基づき算定し

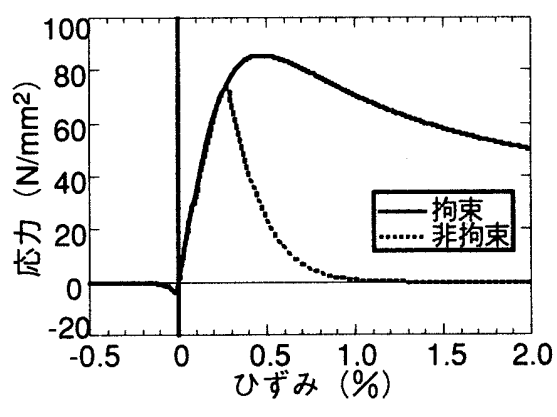

図 7 コンクリートの㐫カーひずみモデル
た結果である。なお，No.4試験体ではねじりの影響を考慮していな い。また，せん断破壊したNo.5では，実験值の方が各計算值より大 きく，既往のせん断酎力式で安全側に評価できること（図5参照） が分かった。

\section{2 復元力特性算定}

曲げ破壊し，ねじりの影響が少なかったNo.1〜No.3の試験体につ いて復元力特性を次のように算定した。

表 4 終局耐力の比較一筧

\begin{tabular}{|c|c|c|c|c|}
\hline \multirow{2}{*}{ 試験体No. } & \multicolumn{3}{|c|}{ 最大耐力 $(\mathrm{kN} \cdot \mathrm{m})$} & \multirow{2}{*}{$\frac{\text { 内：実/竐 }}{\text { 実験值 }}$} \\
\hline & 計算值 ${ }^{\mathrm{a}}$ & & 日十解析值b) & \\
\hline 1 & $\begin{array}{l}7680 \\
(1.14)\end{array}$ & & $\begin{array}{l}8110 \\
(1.08)\end{array}$ & 8730 \\
\hline 2 & $\begin{array}{l}6110 \\
(1.09)\end{array}$ & & $\begin{array}{l}6430 \\
(1.03)\end{array}$ & 6630 \\
\hline 3 & $\begin{array}{c}7280 \\
(1.02)\end{array}$ & & $\begin{array}{c}6640 \\
(1.11)\end{array}$ & 7390 \\
\hline 4 & $\begin{array}{l}6160 \\
(1.19)\end{array}$ & & $\begin{array}{l}7110 \\
(1.03)\end{array}$ & 7320 \\
\hline \multirow{2}{*}{$\begin{array}{c}5 \\
\text { (せん断) }\end{array}$} & 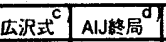 & NewRC & マクロモデル & 実験値 (kN) \\
\hline & \begin{tabular}{|c|c|}
1590 & 1360 \\
$(1.07)$ & $(1.25)$ \\
\end{tabular} & \begin{tabular}{|c|}
1570 \\
$(1.08)$ \\
\end{tabular} & $\begin{array}{c}1580 \\
(1.07)\end{array}$ & 1700 \\
\hline
\end{tabular}

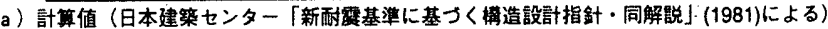
No.1, 2, 4

$M w U=0.9 a t \cdot \sigma y \cdot D+a w \cdot \sigma w y \cdot D+0.5 N \cdot D \cdot\left(1-\frac{N}{B \cdot D \cdot F C}\right)$

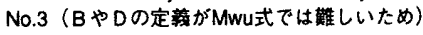

Mwu2 $=a t \cdot \sigma y \cdot t_{w}+0.5 a w \cdot \sigma w y \cdot l w+0.5 \mathrm{~N} \cdot \mathrm{lw}_{\mathrm{w}}$

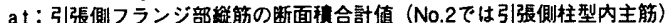

$\sigma y: a t$ :対俯する維施の材料強度

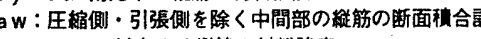

$\sigma w y ： a w に$ 対度する䋖能の材料強度

D：预力壁の全長

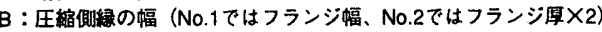
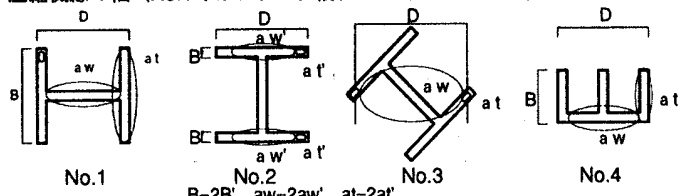

b) 平面保持を仮定した断面 (ファイバーモデル) 解析

c) 広沢式 (世九断)

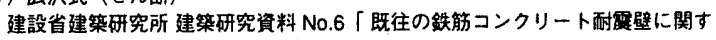
る実倹㾞料とその解析」（1975）による。

Qsu $=\left\{\frac{0.0679 \times P_{t e}^{0.23} \times\left(\sigma_{B}+180\right)}{\sqrt{\mathrm{M} / \mathrm{QLW}+0.12}}+2.7 \sqrt{\mathrm{PW} \cdot \mathrm{w} \sigma_{y}}+0.1 \sigma_{0}\right\} \cdot b_{\theta} \cdot$ Doc口45度

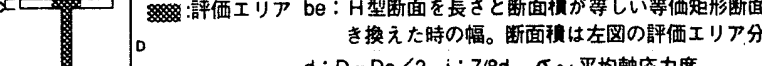
$\mathrm{d}: \mathrm{D}-\mathrm{Dc} / 2 、 \mathrm{j}: 7 / 8 \mathrm{~d} 、 \sigma_{0}:$ 平均朝庞力度

d) AlJ终局

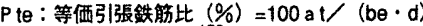

日本建策学会「鉄筋コンクリート造建物の終局望

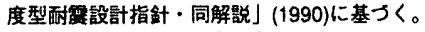

ただし、等価壁長さ算定は右图による。

ө) NewRC式

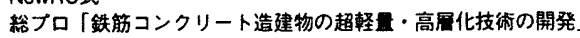

平成4年度䗷造性能分科会報告書による。

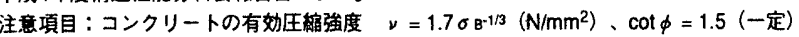

f) マクロモデル (白石式)

日本コンクリート工学協会「RC耐霞臂のマクロモデルとミクロモデルに関するパネル デスカッション」論文集（1998.1）による。

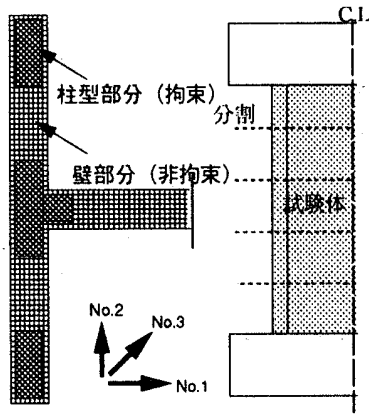

図 8 曲げ解析モデル 

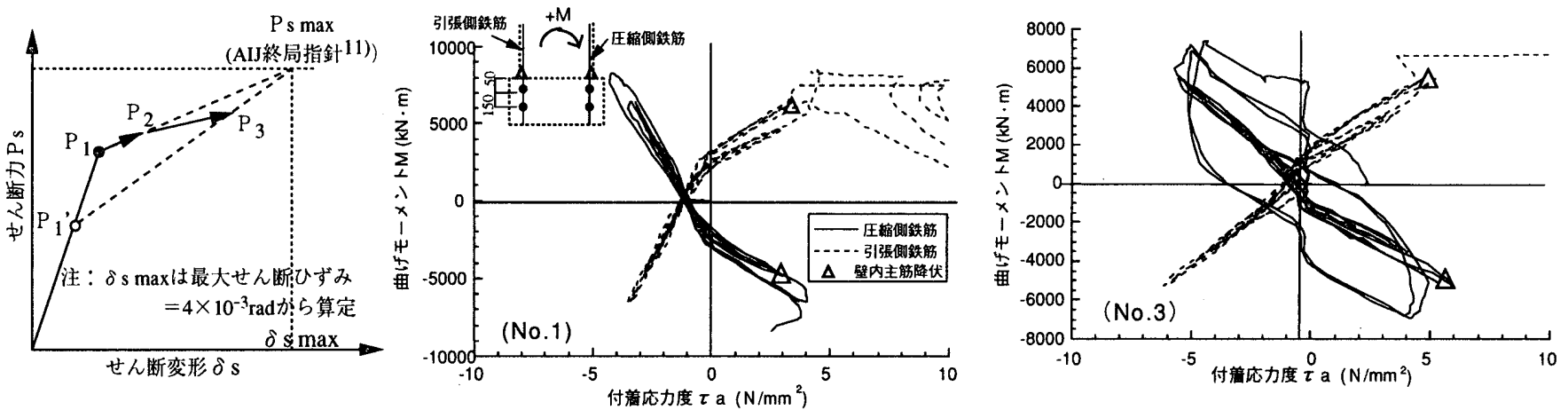

図 9 せん断カ一せん断変形関係概要

図11 脚部モーメントー付着応力度関係

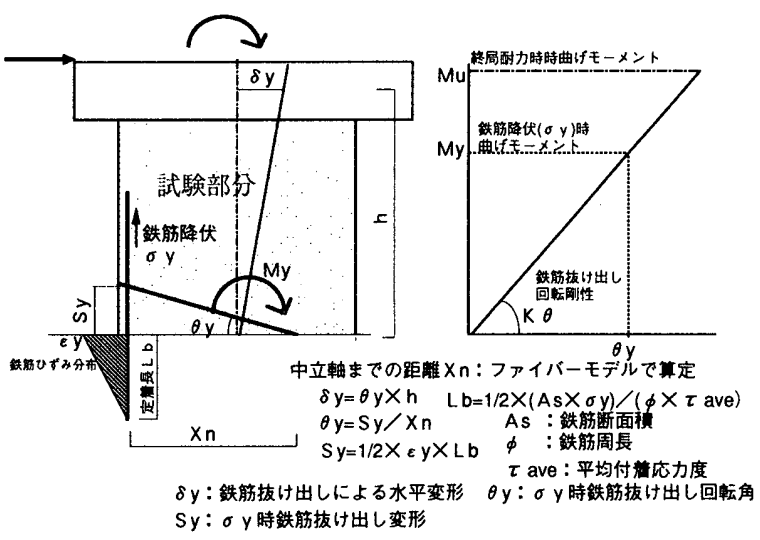

図10鉄筋の抜け出し概要

a. 曲げ荷重 $P_{B}$ 一曲げ変形 $\delta_{\mathrm{B}}$ 関係

H 形試験体No.1 No.3について図8に示すように試験体を高さ方 向に 5 つの領域に等分割し, ファイバーモデル解析によって各領域 の下端水平断面に作用している軸力とモーメントに対応する曲率を 求めた。さらに, 各領域の曲率は下端断面の曲率に等しく曲率は階 段状に分布すると仮定し，2 度積分をして変形を求めた。この解析 では，図8に示すように水平断面を小要素に分割した。No.3では, 加力直交方向に関しても力がゼロになるように変形を与えつつ，加 力方向の $\mathrm{P}_{\mathrm{B}}-\delta_{\mathrm{B}}$ 関係を求めた。

b. せん断荷重 $\mathrm{P}_{\mathrm{s}}$ 一世ん断変形 $\delta_{\mathrm{s}}$ 関係

No.1ではウエブ壁, No.2では 2 枚のフランジ壁をせん断抵抗要素 と仮定した。一定軸力下でのせん断荷重 $\mathrm{P}_{\mathrm{s}}$ 一せん断変形 $\delta$ s 特性は バイリニア型とし, 弾性剛性 $K_{s}$ と第一折れ点強度 $P_{I}$ を式(1)で算定 した。

$$
\begin{aligned}
& K_{S}=E_{S} \cdot A_{S} /\left(\kappa_{w} \cdot h_{0}\right) \\
& P_{1}=A_{S} \cdot \sqrt{\left(f_{t}\left(f_{t}+\sigma_{0}\right)\right)} / \kappa_{w}
\end{aligned}
$$

$E s$ : コンクリートのせん断弾性係数, As : せん断抵抗要素断面積, $\kappa_{w}$ : 形状係数 $(1.08)^{12)}, h_{0}$ : 壁クリアスパン $2400 \mathrm{~mm}, f_{t}$ : コンク リートの引張り強度 $\left(0.33 \sqrt{\sigma_{B}}\left(\mathrm{~N} / \mathrm{mm}^{2}\right)\right), \sigma_{0}:$ 平均軸方向応力度

例えばNo.1では, 式(1)中の $\sigma_{0}$ は, 図8に示したファイバーモデル で曲げ変形を算定する時に最下層の断面におけるウェブ範囲の要素 の応力を総和し，これをウェブの断面積で除した值とした。従って， $\sigma 0$ は断面の曲率に応じて変動する值となる。終局点の強度は, 日 本建築学会(AIJ) R C 造建物の終局強度型耐震設計指針 11 1)によって 求めたせん断終局強度Ps maxとし, その時の変形は, 既往の研究 12$)$ をもとに $\delta \mathrm{s} \max =h_{0} \cdot 4 / 1000$ と仮定した。作用せん断力に応じて脚 部断面の曲率が変化するため式(1)による第一折れ点強度が変動す
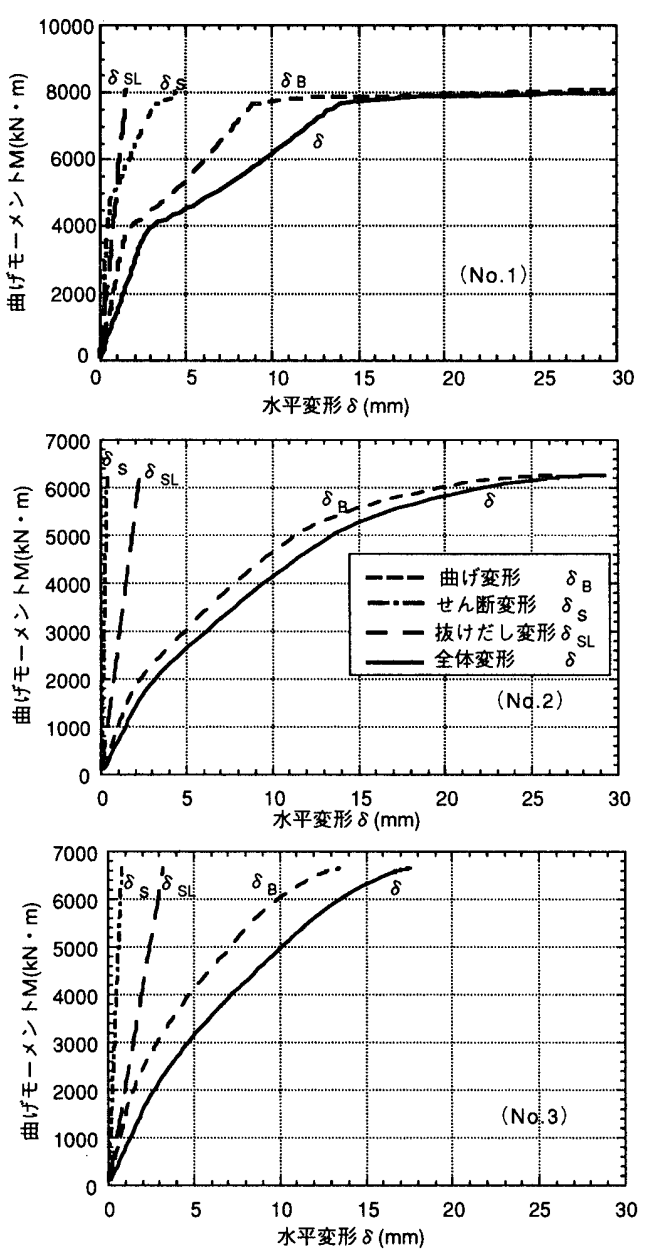

図12 解析における各種変形状況

る。このため $\mathrm{P}_{\mathrm{s}}-\delta_{\mathrm{s}}$ 特性は, 図9のように時々刻々変化するモデ ルとなっている。

No.3では, ウエブ壁と 2 枚のフランジ壁全てをせん断要素とし, 各壁の面外抵抗力は小さいとして無視した。各壁が加力方向と $45^{\circ}$ の角度をなし, 直交方向の力がゼロという条件では, 外力が $\mathrm{P}_{\mathrm{s}}$ の 時ウエブ壁の面内せん断力は $1 / \sqrt{2} \mathrm{P}_{\mathrm{S}}$ となる。上記の方法で求め

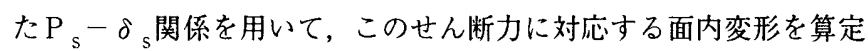
し、これを $1 / \sqrt{2}$ 倍したものを加力方向の変形とした。No.1では作 用せん断力が第一折れ点強度を超えたが, No.2とNo.3では超えなか ったため $\mathrm{P}_{\mathrm{S}}-\delta_{\mathrm{S}}$ 関係は線形となっている。

c. 水平力 $\mathrm{P}_{\mathrm{SL}}$ - 基礎からの鉄筋の抜け出し変形 $\delta$ SL

鉄筋の抜け出しに関しては耐震壁及び柱・梁接合部の研究で様々 な検討がなされている。また，この抜け出し変形が全体変形に与え 
る影響が大きいことも分かっている。鉄筋の抜け出し量を算定する には，簡易的に定着長を仮定し，この範囲では鉄筋とコンクリート 間の付着応力度は一定として算出することが多い。例えば，稲田 131 は原子力発電所建屋耐震壁を対象に，図10に示すように鉄筋の抜け 出し変形を提案し，鉄筋降伏時の基礎内鉄筋の定着長を40d（d：鉄 筋の直径）と仮定して抜け出し量を算定した。今回の鉄筋径である と平均付着応力度 $\tau$ ave $=3.6 \mathrm{~N} / \mathrm{mm}^{2}$ となる。李 14) は R C 柱のマルチ スプリングモデルの特性を決める際に, Lai ${ }^{15)}$ にならって、 ave $=1.17 \sqrt{\sigma_{\mathrm{B}}} \mathrm{N} / \mathrm{mm}^{2}$ と仮定している。基礎のコンクリート強度（ $\sigma$ $\left.{ }_{\mathrm{B}}=43 \sim 45 \mathrm{~N} / \mathrm{mm}^{2}\right)$ を用いると， $\tau$ ave $=7.7 \mathrm{~N} / \mathrm{mm}^{2}$ 程度となる。このよ うに各研究者で付着応力度が大きく異なっている。曲げ変形がせん 断変形より大きく卓越するコア壁では，付着応力度の仮定が難しい ため，各試験体の基礎スラブ上端から基礎内（50mm,200mm）に鉄 筋ひずみゲージを貼付し，この弾性範囲内のひずみの値からこの区 間の付着応力度 $\tau$ a老式 (2)で算定した。

$\tau_{a}=\left(\varepsilon_{i+1}-\varepsilon_{i}\right) \cdot A s \cdot E s /(\phi \cdot \Delta L i)$

$\varepsilon_{i+1}, \varepsilon_{i}$ : 対象区間両端の鉄筋ひずみ計測值, As : 主筋の断面積, Es：主筋のヤング係数， $\phi$ : 主筋の,周長, $\Delta L i ：$ ゲージ間距離
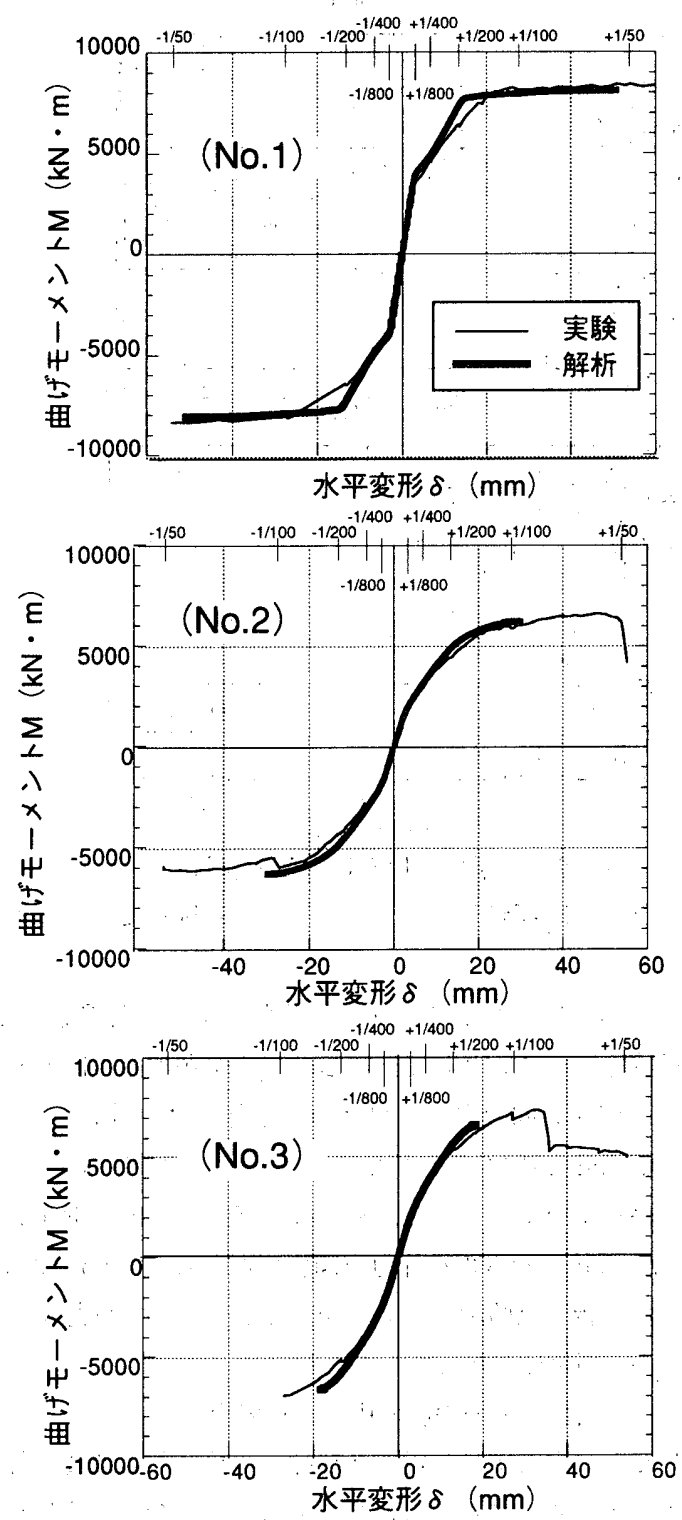

図13 実験結果と解析結果の包絡線比較
上記により求めた付着応力度と脚部曲げモーメントの関係を No.1,No.3について図11に示す。この図から $\tau \mathrm{a}=4.0 \sim 6.0 \mathrm{~N} / \mathrm{mm}^{2}$ まで の範囲で付着応力度は線形となっている。柱型主筋が危険断面で降 伏したときの平均付着応力度を実験での平均值 $\tau$ ave $=4.5 \mathrm{~N} / \mathrm{mm}^{2}$ とし て図10のように定着長Lbを考えると，おおよそ32dとなる。この最 外縁の鉄筋が降伏する時の中立軸位置をファイバーモデル解析より 求めこれを回転中心とし，32dの長さで鉄筋は抜け出すとすると回 転角 $\theta y$ を算出できる。この回転角から加力点（高さ $2700 \mathrm{~mm}$ ）にお ける水平変形に変換し，これを再外縁の鉄筋が降伏する時の鉄筋の 抜け出し変形とした。水平力と鉄筋の抜け出し変形は，稲田と同様 に図10右図とし，その関係を求めた。

以上の 3 種類の荷重－変形関係から復元力を算定する。全体变形 $\delta$ は, 曲げ変形 $\delta{ }_{b}$, せん断変形 $\delta{ }_{s}$ ，基䃈加らの鉄筋の抜け出し 変形 $\delta_{S L}$ の和とした。

$$
\delta=\delta_{B}+\delta_{s}+\delta_{S L}
$$

図12に以上の仮定から求めた復元力を示す。この図より，c.基礎 からの鉄筋の抜け出し变形 $\delta{ }_{s L}$ が比較的多く，曲げひび割れ発生前 では全体変形の約30～50\%となっている。終局耐力までの解析によ る復元力と実験の包絡線の比較を図13に示す。解析は，実験の包絡 線と良く一致した結果となっており，実用的には十分であると考え られる。開断面コア壁は加力方向により䩗性能が異なるが，上記の 解析でも (1)強軸 $\rightarrow$ (2)弱軸 $\rightarrow$ (3)斜軸の順に勒性が低下し実験と同傾向 となった。また，稲田提案の中の $L b=40 \mathrm{~d}$ で鉄筋の抜け出し変形を 計算しても，図13はあまり变化せず，定着長は $L b=30 \mathrm{~d} \sim 40 \mathrm{~d}$ 程度 と考えればよい。実物では，地下の連続壁，または大きな基礎梁に 壁主筋は定着されるが，本実験と同様に抜け出しが生じると思われ るため今後，実務設計上も配慮する必要がある。

\section{4. 立体耐震壁設計法の提案}

4.1 設計用曲け耐力

コア壁を有する構造では、曲げ耐力をどのように定義するかが重

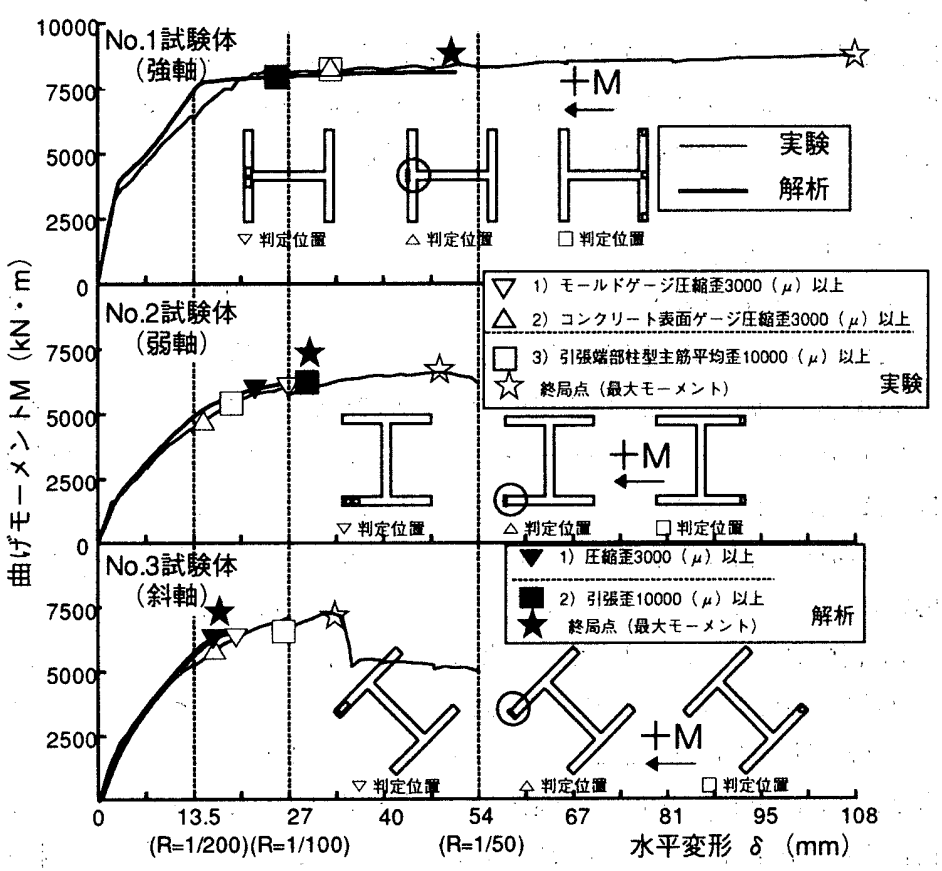

図14 実験と解析における終局耐力とひずみ值 
要となる。高層建物のコア壁の耐震設計では，壁を曲げせん断棒と したモデルによって地震応答解析を行い, 壁の応答最大モーメント に対する設計用曲げ終局耐力との比較で耐震安全性をチェックする ことにしている。ここでは, 設計用曲げ耐力を, ファイバーモデル 解析において，最外縁のコンクリートの圧縮ひずみが $0.3 \%$ あいい, 鉄筋の引張ひずみが1\%の時を曲げ終局耐力と定義する。コンクリ ートの $0.3 \%$ ひずみはACI規準などで通常用いられている值である。 鉄筋の $1 \%$ ひずみは，高強度鉄筋を用いてもひずみ硬化領域に入ら ない程度の值とした。実験と解析において，この想定した設計用曲 げ終局耐力点について比較を行った。

実験ではコンクリートのひずみを最外縁に設置したコンクリート 表面ゲージと，柱型領域の最外位置に設置したモールドゲージによ って測定した。鉄筋ひずみは引張ひずみが最大となる最外柱型主筋 位置にゲージを貼付しその值を測定した。図14に計測結果と前述の ファイバーモデルによる曲げ解析による結果を比較して示す。実験, 解析での終局点を最大モーメント時とすると，圧縮ひずみ $0.3 \%$ し くは，引張ひずみ $1 \%$ の曲げ終局クライテリアは，本実験結果に対 して余裕があり，実験の終局点の半分以下の変形内に収まる結果と なった。今回設定した設計用曲げ終局耐力で，実験結果を安全側に 評価できた。

\section{2 曲げ勒性能の確保}

コア壁を有する曲げ変形型の架構では，上述の設計用曲げ終局 耐力以降も勒性能を有することが耐震設計上重要である。壁脚部が 曲げ降伏以降，図15に示すよう曲げヒンジとなる場合においても， 設計上大地震時の許容変形角を設定し, 動的応答結果や静的漸増解 析において，この許容変形角以内となるようにする必要がある。特 にL形断面の壁や本研究の試験体のような開断面の壁では加わるモ ーメントの方向によっては壁の隅角部や端部に大きな圧縮力が作用 することがあり得る。曲げ変形性能確保のためには圧縮域のコンク リートを横補強筋で拘束することが必要となるため，以下のような 拘束筋の設計法を提案した ${ }^{16}$ )。

設定許容変形角 $R U$ (図15の建物に作用寸る水平力の重心位置 $\mathrm{H}$ における基礎からの相対変形角 Rで定義する）に対応する危険断面 の曲率を要求曲率 $\phi_{\|}$とし，式(4)で算定する。

$$
\phi_{U}=R_{U} / L_{h}
$$

$L_{h}:$ 壁の加力方向投影長さ $\left(L_{w}\right)$

平面保持断面解析 (ファイバーモデル) では，ある曲率 фを与之 た際に断面内でのひずみ分布が計算できる。横補強筋による拘束が ない場合には，ひずみがプレーンコンクリートの最大圧縮ひずみ $\varepsilon$ より大きい範囲で，コンクリートはひずみ軟化域に入る。曲げ破 壊型の壁の最大耐力後の耐力低下は，ひずみ軟化域のコンクリート の応力低下が原因となるので，この部分のコンクリートを拘束する ことにより勒性能を確保することができる。図16に示すような 。 を越える領域において圧縮強度 $\sigma_{\mathrm{P}}$ を保持できる仮想コンクリート が使用できれば強度低下は生じない。しかし実際には，このような 仮想コンクリートを作ることはできないので，仮想コンクリートを 用いた断面解析より得られた拘束範囲の最外縁ひずみ $\varepsilon$ に対応す る応力度が。, となるように拘束することで，仮想コンクリートに 近い性状を与えることにする。ただし被りコンクリートの剥落の影
響は小さいとみなす。この条件を満たすために必要な拘束コンクリ 一トの圧縮強度 ${ }_{R} \sigma_{\mathrm{C} B}$ は式(5)で算定する。この式は，孫・崎野によ る拘束コンクリートの応力ー歪関係モデル9) より導いた。

${ }_{R} \sigma_{C B}=\left(0.02644 \sigma_{P}^{2}-8.875 \sigma_{P}+5974\right) \varepsilon_{U}+\left(0.9366 \sigma_{P}+22.73\right) \cdot \cdot(5)$

$\sigma_{C B}=\sigma_{P}+\kappa \cdot \rho \cdot \sigma_{w y}$

$\kappa=11.5 \frac{d^{\prime \prime}}{C}\left(1-\frac{S}{2 D_{C}}\right)$

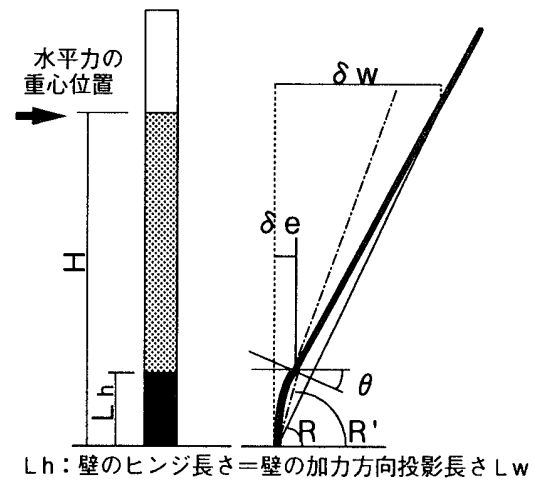

図15 コア壁の変形状況
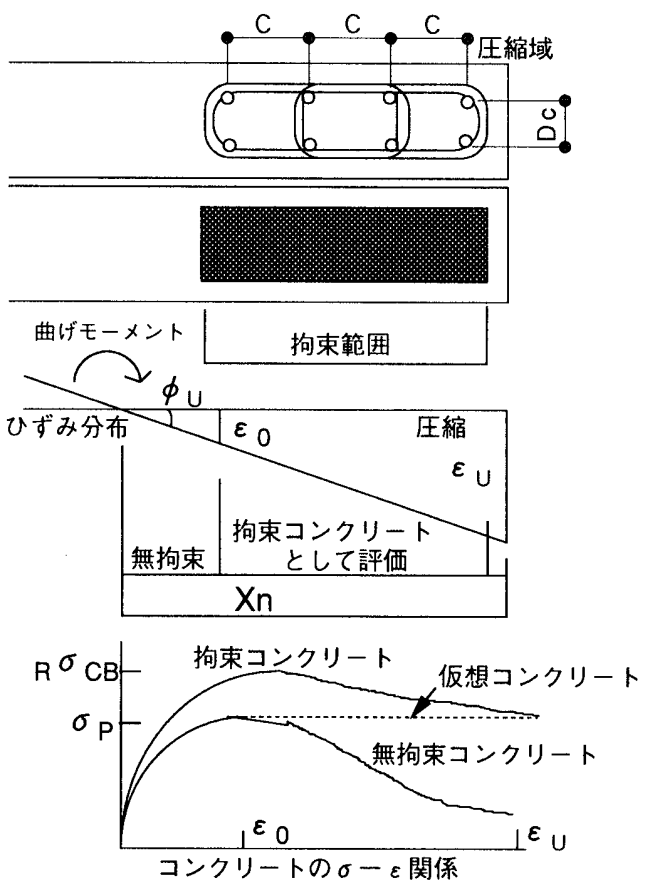

図16 拘束範囲の求め方

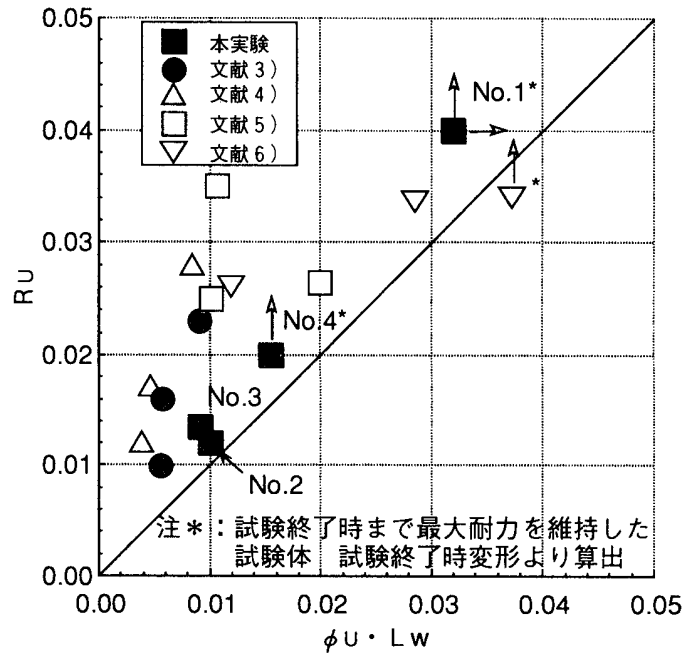

図17 限界変形角と曲率の関係 
$d^{\prime \prime}$ : 横補強筋の直径, $S$ : 横補強筋間隔, $\rho$ : 横補強筋体積比, $\sigma w y$ : 横補強筋降伏強度

横補強笳の配筋を仮定し，式(6)，(7)によって計算した拘束コンクリ 一トの圧縮強度 $\sigma_{\mathrm{CB}}$ が $_{\mathrm{R}} \sigma_{\mathrm{CB}}$ を上回っていれば拘束量は十分となる。 不足の場合は横補強筋の間隔や径で調節する。拘束量域が長方形の 場合，D c は縦横の小さい方の辺の值を，Cは大きい方の辺の值を 用いる。

ただし曲率が大きい場合，式(5)で設計可能となったとしても，そ の時の主筋やコンクリートのひずみが過大にならないように，コン クリートの圧縮縁ひずみが1.0\%，あるいは鉄筋の引張ひずみが $8 \%$ になる時を限界変形角の上限としファイバーモデル解析に制限を設 けた。コンクリートの上限値1.0\%は中心軸圧縮実験 17)を参考に 定め, 鉄筋の上限値 $8 \%$ は高強度鉄筋においても一様伸びが期待で きるひずみの限界值とした。

この設計法の妥当性を, 今回実施した試験体と既往の L 形断面耐 震壁の実験結果 3 ) ～6) と比較することにより検証した。まず，仮 想コンクリートを用いた断面解析から求められる必要な拘束範囲 が，実際の試験体の拘束範囲に等しくなるときの曲率 $\phi_{\mathrm{u}}$ を求めた。 次に， $\phi_{\mathrm{U}}$ とプレーンコンクリートの圧縮強度 $\sigma_{\mathrm{F}}$ から, 式(5)により 必要な拘束コンクリート強度 $\sigma_{\mathrm{R}} \sigma_{\mathrm{CB}}$ を算定した。すべての試験体に おいて, 試験体の拘束筋量を用いて式(6)，(7)によって算定した実際 の拘束コンクリート強度 $\sigma_{C \mathrm{~B}}$ が必要強度 ${ }_{\mathrm{R}} \sigma_{\mathrm{CB}}$ を上回っていたので, $\phi_{U}$ に壁の加力方向投影長さ $L_{W}$ を乗じた值を，この試験体の限界変 形角の推定值として図17の横軸にプロットした。図17の繸軸は各試 験体の限界変形角の実験值で, 曲げ圧壊が顕著で急激に荷重が低下 するものはその変化点，そうでないものは荷重が最大耐力の $90 \% に$ 低下した点18）での変形角とした。図17から, 限界変形角の実験値 は推定值を上回っており，上記の方法で曲げに対する変形能力を確 保するための横補強筋の設計が可能となることが分かる。

\section{5. まとめ}

本研究では，高強度材料を使用した開断面 R C 立体壁（コア壁） を対象にその構造特性を把握するのために実験及び解析を行った。 また，設計法に関する検討も実施した。以下に，本研究で得られた 主要な成果を示す。

1）開断面コア壁は加力方向により耐力・勒性能が大きく異なるた め設計：解析上留意が必要となる。

2) 開断面コア壁の曲げ最大耐力は, 平面保持を仮定した断面解析 (ファイバーモデル) で推定できた。既往の曲げ略算式で実験 值を安全側に評価できた。せん断耐力は既往の提案式で実験結 果を安全側に評価できた。

3) 曲げの復元力は, ファイバーモデル解析で求めた $\mathrm{M}$ （曲げ）$\phi$ (曲率) を積分し求めた曲げ変形にせん断変形と基礎からの 鉄筋の抜け出し変形を考慮することで，ほほ実験結果をシミュ レーションできた。

4 ）壁曲げ終局耐力は, ファイバーモデル解析でコンクリートの圧

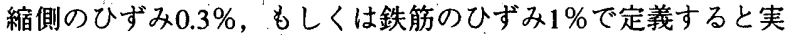
験結果を安全側に評価できた。

5 ) 設計上必要な曲げ勒性能は, 制限すべき変形角に対応する曲率
を求め，この曲率を保証できるようにコア壁の圧縮域のコンク リートを横補強筋で拘束することで確保できる。提案した設計 法により実験結果を安全側に評価できた。

\section{参考文献}

1）竹村寛基, 新田隆雄, 佐藤龍生, 小林淳: センターコア R C 造·外周フ レームS 造の混合構造 (仮称) 日本カーボン横浜工場再開発計画, ビル ディングレター, pp.1〜pp.7，1992年12月

2) 熊谷仁志, 佐竹直紀, 西田朗, 中島秀雄：RCコアウォールシステムの 開発と実証, 日本建等学会技術報告集 第 3 号, pp.151 pp.156, 1996年12月

3 ）小西覚，丸田誠，別所佐登志，鈴木紀雄：鉄筋コンクリート造L型断面耐 震壁に関する実験的研究，コンクリート工学年次論文報告集 Vol 19, No.2，pp.1083 pp.1088，1997年.6月

4）荒井康幸，溝口光男，カイラッラフォアド，山田基彦：二方向水平力と 軸力を受ける鉄筋コンクリートL形断面酎震壁の曲げ終局強度，コンク リート工学年次諭文報告集 Vol 18， No.2，pp.1037 pp.1042，1996年6月

5 ) F.Kfairallah, Y.Arai, M.Mizoguti, C.Takeda : Flexural Behavior of RC LShaped Shear Walls under A Normal Force and BI-Directional Reversal Force, コンクリート工学年次論文報告集 Vol 17，No.2，pp.553～pp.558，1995年6月

6 ）有馬久智，大久保孝雄，壁谷沢寿海：ハイブリッド構造に関する日米共 同構造実験研究(HWS-12,13)－変動軸力を受けるL型壁の実験（実験既要， 実験結果の検討）一，日本建築学会学術講演梗概集（近畿）構造 $\mathrm{N}$, pp.583 pp.586，1996年9月

7）小堀鐸二，大川閏，五十殿侑弘ほか7名：制霆装置を用いた新しいR C 造 架構の開発（その1, その 2 ), 日本建筑学会学術講演梗概集. (北海道) 構造 N, pp.803 pp.806，1995年8月

8 ）丸田誠，别所佐登志，鈴木紀雄，永井覚：H形断面コア壁の構造性能確 認実験（その1，その 2 ），日本建築学会学術講演梗概集（関東）構 造 NV,pp.185 pp.189，1997年9月

9）孫玉平，畸野健治：高強度材料を用いた鉄筋コンクリート柱の勒性改 善に関する策験的研究，コンクリート工学年次論文報告集 Vol 15, No.2, pp.719 pp.724，1993年6月

$10)$ Fafitis,A. and Shah,S.P. : Lateral Reinforcement for High-Strength Columns, ACI SP-87, High-Strength Concrete, pp.213 pp.232, 1985

11）日本建築学会：鉄筋コンクリート造建物の終局强度型耐震設計指針。 同解説, pp.122 pp.131， 1990.

12 ）日本建築学会：鉄筋コンクリート終局强度設計に関する資料 31 世 ん断破壊を起こす楖震壁の力学特性(2)（富井政英編），pp.130～pp.136, 1987年9月

13 ）稻田泰夫：原子炬建屋立体耐霞壁の復元力特性に阅する研究（その2） M- $\phi$ 関係抢よび荷重変形関係スケルトンカーブの検討，AIJ構造系論文報 告集第378号，pp.16〜pp.25，1987年8月

14 ）李康寧，小谷俊介，青山博之：変動軸力の効果を考县したRC平面愲組 の弾塑性地霞応答，コンクリート工学年次論文報告集 Vol 10, No.3, pp.467 pp.472，1988年6月

15 ) Lai,S.S, G.T.Will, S.Otani : Model for Inelastic Biaxial Bending of Concrete Members, ASCE Journal , Vol 110, ST11, pp.2563 pp.2584, 1984

16 ）鈴木紀雄：鉄筋コンクリート造立体耐露壁の曲げ変形性能を確保する ための設計法, 日本建築学会学術講演梗既集（関東）構造 N, pp.197 pp.198，1997年9月

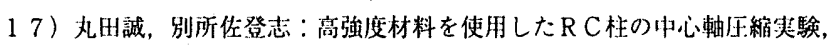
コンクリート工学年次論文報告集 Vol 16， No.2，pp.665～pp.670，1994年6月

18）日本建築学会：鉄筋コンクリート造建物の勒性保証型酎﨡設計指針

（案）・同解説 pp.112 pp.114 pp.126 pp.134，1997年

(1998年 9 月10日原稿受理，1999年 1 月27日採用決定） 